\title{
Amperometric Detection of Hydroquinone and Homogentisic Acid with Laccase Immobilized Platinum Electrode
}

\author{
De Quan* and Woonsup Shin* \\ Department of Chemistry, Sogang Liniversity, Seoul 12/-742, Korea \\ Received Februay /8, 2004
}

\begin{abstract}
DeniLite ${ }^{\mathrm{TN}}$ laccase immobilized platinum electrode was used for amperometric detection of hydroquinone (HQ) and homogentisic acid (HGA) by means of substrate recycling. In case of $\mathrm{HQ}$, the obtained sensitivity is $280 \mathrm{nA} / \mu \mathrm{M}$ with linear range of $0.2-35 \mu \mathrm{M}\left(\mathrm{r}^{2}-0.998\right)$ and detection limit (S/ -3$)$ of $50 \mathrm{nM}$. This high sensitivity can be attributed to chemical amplification due to the cycling of the substrate caused by enzymatic oxidation and following electrochemical regeneration. In case of IIG $\Lambda$, the obtained sensitivity is $53 \mathrm{n} N / \mu \mathrm{M}$ with linear range of $1-50 \mu \mathrm{M}\left(r^{2}-0.999\right)$ and detection limit of $0.3 \mu \mathrm{M}$. The response times (tor $\left.p_{0}\right)$ are about 2 seconds for the two substrates and the long-term stability is 60 days for IIQ and around 40-50 days for IIGA with retaining $80 \%$ of initial activities. The very fast response and the durable long-term stability are the principal advantages of this sensor. pI studies show that optimal pl I of the sensor for IIQ is 6.0 and that for IJG $\Lambda$ is 4.5-5.0. This shift of optimal pI I towards acidic range for I IG $\Lambda$ can be attributed to the balance between enzyme activity and accessibility of the substrate to the active site of the enzyme.
\end{abstract}

Key Words : L accase, Amperometric biosensor, Hydroquinone, Homogentisic acid, Substrate recycling

\section{Introduction}

Hydroquinone (HQ, 1,4-benzenediol) is important in a wide number of biological and industrial processes such as coal-tar production, paper manufacturing, etc.' $\mathrm{HQ}$ has become one of the most widely used organic-reducing agents, especially in photographic developers, the production of polymerization inhibitors, rubber and food antioxidants. ${ }^{2} \mathrm{HQ}$ and its reaction products have been determined in various fields such as cosmetics, hair products and pharmaceutical preparations in both air samples and biological fluids.' Several methods for HQ detection were reported, such as GC-MS, ${ }^{3}$ MS, ${ }^{4}$ chromatography, ${ }^{5}$ HPLC, ${ }_{7}^{7-10}$ etc.

Human metabolic disorders often cause the accumulation of specific metabolites in patients serum and urine." For example, the presence of homogentisic acid (HGA, 2,5dihydroxyphenylacetic acid) in urine is a diagnostic for alcaptonuria. ${ }^{12}$ A massive increase of HGA level in plasma will result primarily in arthropathies, but also other manifestations including cardiovascular and renal disease..$^{\text {is }}$ Therefore, determination of HGA is important in clinical and pharmaceutical research. Several methods for HGA detection were reported, such as CE (capillary electrophoresis)-MS." GC-MS, ${ }^{13}$ JR, $^{14}$ paper chromatography, ${ }^{15}$ HPLC, ${ }^{11.17}$ etc.

Besides above instrumental analysis methods for $\mathrm{HQ}$ or HGA, biosensor methods were also reported. In contrast of easy fabrication, fast analysis, low-cost. etc. for biosensor method, although the instrumental analysis is accurate. specific and sensitive it often requires delicate and time-

Co-corresponding Authors. De Quan (quande $(a \mathrm{kw}, \mathrm{ac} . \mathrm{kr}$ ), Woonsup Shin (shinws $\alpha$ sogang.ac.kr) consuming sample pretreatment prior to the analysis and requires utilization of heavy equipment, therefore, they are inappropriate for massive screening. ${ }^{12.18}$ In reported biosensor methods, for detection of $\mathrm{HQ}$ enzymes such as laccase (T. versicolor) ${ }^{19.20}$ glucose dehydrogenase (GDH, $A$. calcoaceticus), ${ }^{21}$ glucose oxidase (GOD, Aspergillus) ${ }^{22}$ and cellobiose dehydrogenase $(\mathrm{CDH}, P \text {, chrysosporizm })^{23}$ etc. were used, and for detection of $\mathrm{HGA}$ enzymes such as laccase ( $I$.' versicolor). ${ }^{19}$ homogentisate dioxygenase ( $A$. nidulans), ${ }^{2}$ etc. were used. Bacterial sensor based on Zucchini $\left(C^{-} \text {. pepo }\right)^{2}$ or sweet potato tissue modified graphite electrode $\mathrm{e}^{2+}$ for $\mathrm{HQ}$ detection was also reported.

Recently, we reported that laccase purified from Denilite ${ }^{\mathrm{TM}}$ could be successfully covalently immobilized on platinum electrode ${ }^{2.5}$ and the electrode could be used as a biosensor for detection of aromatic diamine and aminophenol, ${ }^{2,}$ catechol and catecholamines ${ }^{27}$ by means of substrate recycling. Laccase ( $p$-diphenol:dioxygen oxidoreductase, EC 1.10.3.2) is a blue multi-copper containing enzyme, which catalyzes the oxidation of a variety of organic substrates such as phenols coupled to the reduction of molecular oxygen to water. $^{28-31}$ In this paper, we describe the application of the sensor for amperometric detection of hydroquinone (HQ) and homogentisic acid (HGA) (Figure 1).

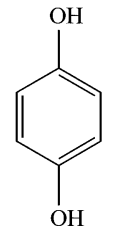

1,4-Benzenediol

(Hydroquinone, HQ)

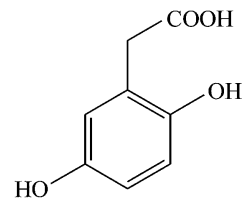

2,5-Dihydroxyphenylacetic acid
(Homogentisic acid, HGA)

Figure 1. Struetures of hydroguinone and homogentisic acid. 


\section{Experimental Section}

Hydroquinone (99\%), homogentisic acid (97\%), p-phenylenediamine (PPD, 98\%), 2,2'-azinobis(3-ethylbenzothiazoline-6-sulfonic acid) (ABTS, 98\%), 3-aminopropyltriethoxysilane (APTFS, 99\%), glutaraldehyde (25\% aqueous solution) and bovine serum albumin (BSA, 98\%) were purchased from Sigma \& Aldrich Co. and used without further purification. Other chemicals were of analytical grade. Deionized water $(18 \mathrm{M} \Omega \mathrm{cm}$ ) from Milli $\mathrm{Q}$ water purification system was used for preparing buffer and stock solutions. Stock solutions of the substrates were prepared just before use and kept in the dark enclosed by aluminum foil under argon until the measurements.

Mcllvaine buffer $\left(0.05 \mathrm{M}\right.$ citric acid $/ 0.1 \mathrm{M} \mathrm{Na}_{2} \mathrm{HPO}_{4}, \mathrm{pH}$ 2.5-8.0) was used for $\mathrm{pH}$ dependence studies. $0.05 \mathrm{M}$ phosphate buffer solution (PBS, $\mathrm{Na}_{2} \mathrm{HPO}_{4} / \mathrm{KH}_{2} \mathrm{PO}_{4}$ ) or Mcllvaine buffer was used for amperometric sensor experiments.

Pt disk working ( $\phi 4 \mathrm{~mm})$. Pt wire counter (spiral), and $\mathrm{Ag} / \mathrm{AgCl}(3 \mathrm{M} \mathrm{KCl})$ reference electrodes were used for electrochemical measurements. BAS $50 \mathrm{~W}$ or cDAQ-1604 (Fibio Co, Korea) potentiostat was used to run CVS and measure current-time responses. The electrochemical cell ( 5 $\mathrm{ml}$. in volume) was equipped in a thermostatic water bath $\left(25 \pm 0.2^{\circ} \mathrm{C}\right)$ and buffer solution was continuously stirred by magnetic bar during amperometric experiments.

I accase was isolated and puritied from Denil ite ${ }^{\mathrm{N} 1}$, which is a commercial product for decolorization of indigo dye fiom Novo Nordisk Co., according to the published method, ${ }^{5.32}$ MГS buffer $(8 \mathrm{mM}, \mathrm{pH} 5.3)$ was used for the activity measurement of the purified laccase. The activity is 65 units mg for ABTS oxidation at room temperature. ${ }^{3.3}$

The covalent immobilization of laccase was done according to the method we previously reported..$^{25.27}$ The method consists of oxidation of $\mathrm{Pt}$ electrode surface, introduction of amine functional group by silanization with APTES, and immobilization of laccase by glutaraldehyde. The amount of immobilized enzyme was fixed by dropping $5 \mu \mathrm{L}$ of $6 \mathrm{mg}$ $\mathrm{mL}$ enzyme solution to the modified electrode surface. ${ }^{20}$ The laccase immobilized electrode was stored in $0.05 \mathrm{M}$ PBS, pH 6.0 at 4 " $\mathrm{C}$ when not in use.

BSA was also immobilized by the same method to test the substrate recycling efficiency. ${ }^{19}$ "The working potentials in amperometric experiments with laccase imınobilized electrode were applied at $100 \mathrm{mV}$ negative (for $\mathrm{HQ}$ ) or $60 \mathrm{mV}$ negative (for HGA) than reduction peak potentials of respective substrates at corresponding $\mathrm{pHs}$. The sensor responses were normalized by those for l'PD to compensate the variations resulted from different fabrications of the enzyme electrodes.

\section{Results and Discussion}

HQ detection. Figure 2 shows the typical steady state current response of the laccase immobilized $\mathrm{Pt}$ electrode to successive $5.0 \mu \mathrm{M}$ increments in $\mathrm{HQ}$ concentrations at $\mathrm{pH}$ 6.0. This $\mathrm{pH}$ is optimal for the substrate detection and will be

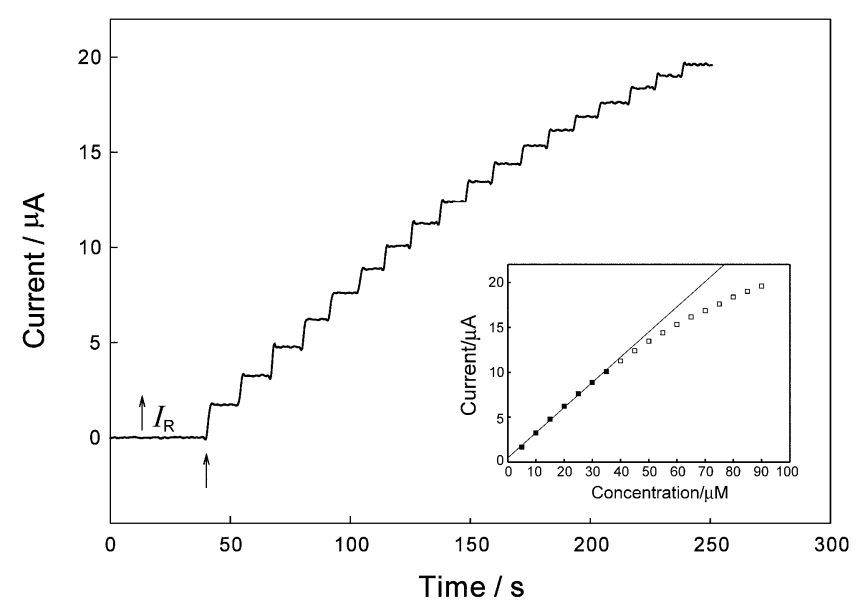

Figure 2. Steady state current response of the lacease immobilized Pt electrode to suecessive $5.0 \mu \mathrm{M}$ inerements for hydroquinone in phosphate buller at $\mathrm{pH} 6.0$. The applied potential is $-130 \mathrm{mV}$ vs. $\wedge \mathrm{g} / \Lambda \mathrm{gC}$, Inset: Calibration curve.

discussed in the following section. Substrate concentrations were changed by stepwise addition of a concentrated solution to a stirred buffer. As can be seen in Figure 2, the current response is very stable and fast with around 2 seconds response time $\left(\mathrm{t}_{1}, \mathrm{y}_{4}\right)$. The inset of Figure 2 shows the sensitivity of the sensor for $\mathrm{HQ}$ is $280 \mathrm{nA} / \mu \mathrm{M}$, the linear response range is $0.2-35 \mu \mathrm{M}\left(r^{2}=0.998\right)$.

We already reported the similar stable and fast response of the laccase immobilized Pt electrode used as a biosensor ${ }^{20.27}$ and attributed these characteristics to the covalent inmobilization. Undoubtedly, covalent immobilization can provide the most stable enzyme loading. Furthermore, covalent immobilization could make the redox cycle of the substrate to take place on the surface very closely and minimize the diffusional resistance of the substrate. Comparatively, response times of some reported sensors for HQ are $5 \mathrm{~s}, 90 \mathrm{~s}$ and 7.5 min for laccase, ${ }^{19} \mathrm{GDH}^{21}$ and $\mathrm{GOD}^{22}$ immobilized sensor, respectively.

It was reported that sensitivity of $T$. versicolor laccase immobilized sensor prepared by using reticulated vitrious carbon electrode $(\phi 5 \mathrm{~mm})$ impregnated with epoxy resin (Epoxy-RVC) for $\mathrm{HQ}$ was about $120 \mathrm{nA} / \mathrm{M}$ at $\mathrm{pH} 5.5 .^{19}$ and that of $T$ versicolor or $C$. hirsutus laccase adsorbed graphite electrode $(\phi 3.05 \mathrm{~mm})$ for the substrate was 183 or $145 \mathrm{nA} / \mu \mathrm{M}$ at $\mathrm{pH} 5.0^{20}$ The sensitivity of the sensor reported here combined with these reported sensitivities can be sequentially converted to relative ones of $100 \%, 27 \%$, $112 \%$ and $89 \%$. Taken into account of the fact that $\mathrm{rlA}$ (flow injection analysis) mode were employed in case of graphite electrode $(\phi 3.05 \mathrm{~mm})$ the sensitivity reported here may be said highly improved. The detection principle in this study is substrate recycling, i.e. enzymatic oxidation of substrate followed by electrochemical regeneration. Obviously, the cycling of the substrate between laccase and electrode is quite efficient. Although exact reason for the improved sensitivity of the sensor is not fully understood several effects may be included such as the high affinity of the 
enzyme for the substrates, the increased catalytic rate of the enzyme, and the better mobility of the substrate in the enzyme layer. ${ }^{27}$ Besides laccases, other enzymes were also immobilized for HQ detection, and the converted relative sensitivities are as follows: 100\%, 125\%,70\% and 4000\% for this study, $\mathrm{CDH}$ (FIA mode), ${ }^{23} \mathrm{GOD}^{22}$ and $\mathrm{GDH}^{21}$ immobilized sensor, respectively. Therefore, except for the sensitivity of $\mathrm{GDH}$ modified carbon paste electrode, an unusual highly amplified one, it can be concluded that sensitivity of the laccase immobilized sensor reported here is totally comparable with those of reported other enzymes immobilized ones.

The relative standard deviation (R.S.D) of the current response for successive measurements for $\mathrm{HQ}$ is $3.1 \%$ ( $\mathrm{n}=$ 7). The obtained amplification factor (A.F.) for $\mathrm{HQ}$ is 19 , which is perfectly comparable to Wasa et al reported value of $18^{(4)}$ or Lindgren et al reported value of $19 .^{23}$ The obtained linear response range is $0.2-35 \mu \mathrm{M}\left(\mathrm{r}^{2}=0.998\right)$, which is superior to that of $T$. versicolor laccase adsorbed graphite electrode, i.e. $0.5-8 \mu \mathrm{M}^{20}$ or that of GOD immobilized sensor, i.e. upper limit of $4 \mu \mathrm{M}^{22}$ The relatively low sensitivity in high substrate concentrations can be ascribed to saturation of the enzyme active site by the substrate or formation of polymer film on the enzyme layer upon oxidation. It is known that oxidation of HQ by laccase can lead to polymerization. ${ }^{30}$ The detection limit can be estimated to be $50 \mathrm{nM}(\mathrm{S} / \mathrm{N}=3)$ with the background noise of about $5 \mathrm{nA}$. The detection limit of 7 . versicolor laccase immobilized sensor for $\mathrm{HQ}$ is $440 \mathrm{nM}^{20}$ or $600 \mathrm{nM},{ }^{3.1}$ and that of $\mathrm{CDH}$ immobilized sensor or GOD immobilized sensor is $3.5 \mathrm{nM}^{2.3}$ or $1 \mathrm{nM}^{22}$ In spite of the similar sensitivities among the sensor reported here, $\mathrm{CDH}$ sensor and GOD sensor the obtained detection limit in this study is relatively high, which may be due to the relatively high background noise possibly caused by the strong modification condition. It was reported that $\mathrm{CDH}$ was immobilized by adsorption $^{2.3}$ and GOD was done by entrapment behind polymer membrane.22 The long-term stability of the sensor is 60 days for $\mathrm{HQ}$ with retaining $80 \%$ of initial activity. Wasa et al reported that $T$. versicolor laccase immobilized EpoxyRVC sensor retained about $65 \%$ of initial activities after repetitive use for 2 months. ${ }^{19}$ Wollenberger et al reported that response of GDH modified carbon paste electrode dropped by $50 \%$ after 10 days $^{21}$ and Lindgren et al reported that half the response remained after storage in $4{ }^{\circ} \mathrm{C}$ for I week for $\mathrm{CDH}$ sensor.". The very fast response and the durable long-term stability are the principal advantages of the laccase covalently immobilized sensor.

$\mathrm{pH}$ profile of the laccase immobilized sensor for $\mathrm{HQ}$ shows bell-shaped profile with the optimal $\mathrm{pH}$ of 6.0 (Figure 3). From the principle of substrate recycling employed in this study, sensitivity of the sensor is mainly determined by two factors, i.e. enzyme activity and reversibility of the substrate. Jo check the reversibility, $\mathrm{CV}$ s of $\mathrm{HQ}$ were run on bare $\mathrm{Pt}$ electrode from $\mathrm{pH} 4$ to 7 . 'The reversibility of the substrate did not show remarkable change upon changing $\mathrm{pH}$ in this range (data not shown). Therefore, for $\mathrm{HQ}$, only

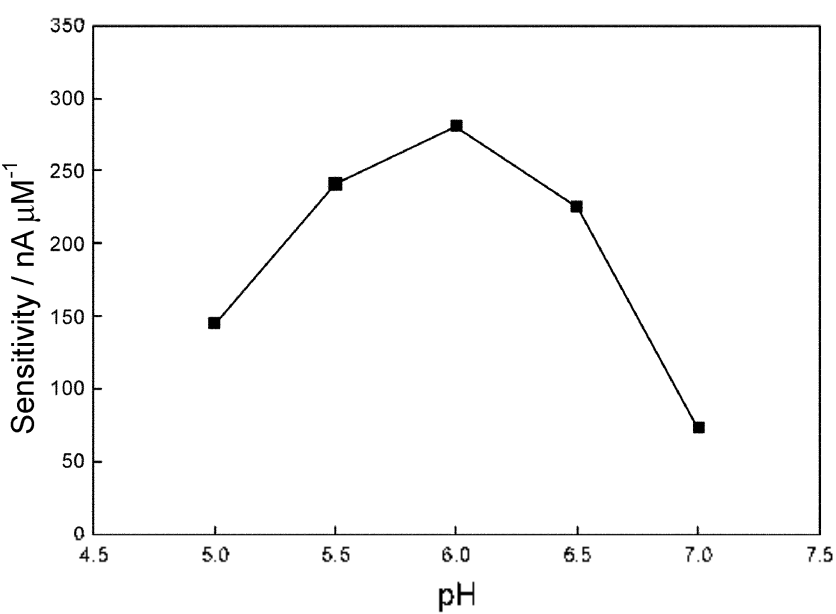

Figure 3. pH dependence of the laccase immobilized Pt electrode in Mellvaine butfer for hydrocuinone.

enzyme activity will control the $\mathrm{pH}$ profile. We have reported that the optimal $\mathrm{pH}$ of the sensor for $\mathrm{PPD}$ is 6.0 and explained this $\mathrm{pH}$ profile by $\Delta \Gamma^{0}$ effect and $\mathrm{OH}^{-}$inhibition. ${ }^{26}$ Both $\mathrm{PPD}$ and $\mathrm{HQ}$ are the typical substrates for laccases. ${ }^{29-31}$ Therefore, obtained optimal $\mathrm{pH} 6.0$ for $\mathrm{HQ}$ can be said reasonable. It was reported that $T$. versicolor laccase immobilized F:poxy-RVC electrode showed optimal $\mathrm{pH}$ at $5,0-5.5^{19}$ and the same enzyme adsorbed graphite electrode showed optimal $\mathrm{pH}$ at $5.0 .^{20} \mathrm{lt}$ is worthy to note that in these cases the optimal $\mathrm{pH}$ for the sensors are also the optimal $\mathrm{pH}$ for $T$. versicolor laccase. Obviously, these differences in optimal $\mathrm{pH}$ for the different laccases immobilized sensors are mainly resulted from the different sources from which laccases are purified.

HGA detection. Figure 4 shows the typical steady state current response of the laccase immobilized sensor to successive $5.0 \mu \mathrm{M}$ increments in HGA concentrations at $\mathrm{pH}$ 5.0 . The current response is also very stable and fast with around 2 seconds response time $\left(t_{9}\left(r_{0}\right)\right.$ ). The inset of Figure 4 shows the sensitivity of the sensor for $\mathrm{HGA}$ is $53 \mathrm{nA} / \mu \mathrm{M}$.

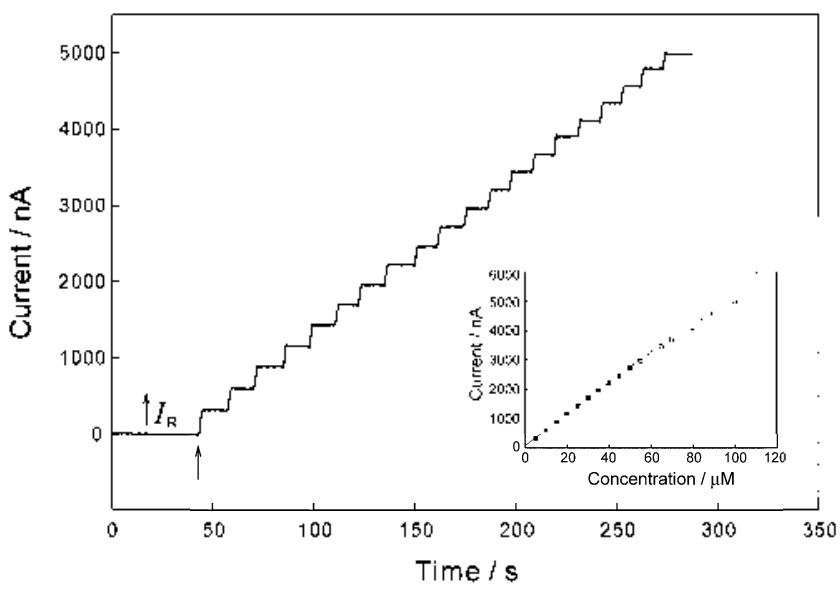

Figure 4. Steady state current response of the laccase immobilized Pt electrode to successive $5.0 \mu \mathrm{M}$ increments for homogentisic acid in Mellvaine buffer at pll 5.0. The applied potential is $-130 \mathrm{mV}$ w. Ag/AgCl. Inset: Calibration curve. 
the linear response range is $1.0-50 \mu \mathrm{M}\left(r^{2}=0.999\right)$.

Although the determination and quantification of HGA is important in clinical field as mentioned in introduction section, as far as we know, reports on the detection with electrochemical biosensor are rare in literature. Therefore. we can not fully compare our result with those of others. however, at the same time it may provide a possibility of the sensor to be used in real sample determination. Due to the basic structure of $\mathrm{HQ}$ for $\mathrm{HGA}$, we also tested the detection with laccase immobilized biosensor. As early as 1984, Wasa et al. reported that sensitivity of $T$. versicolor laccase immobilized epoxy-RVC electrode ( $\phi 5 \mathrm{~mm}$ ) for HGA was about $26 \mathrm{nA} / \mu \mathrm{M} .{ }^{10}$ Compared with this value the sensitivity of the sensor reported here is about 3 times higher. Another reported detection in which enzyme was used is made by spectrophotometric detection by use of homogentisate dioxygenase. ${ }^{12}$ Therefore, we can not compare the sensitivity reported here with that of the spectrophotometric method. The sensitivity of $53 \mathrm{nA} / \mu \mathrm{M}$ of the sensor for HGA is only about $20 \%$ of that for $\mathrm{HQ}$, which means that substrate recycling for HGA is prohibited to some extent, which is mainly resulted from the relatively worse reversibility of HGA and limited accessibility of the substrate to the active site of the enzyme, which will be discussed in following section on $\mathrm{pH}$ effect.

The R.S.D value of the current response for successive measurements for HGA is $3.7 \%(\mathrm{n}=7)$. The obtained A.F value for HGA is 9, which is much lower than Wasa et al reported value of $18 .^{19}$ The detection limit of the sensor reported here can be estimated to be $0.3 \mu \mathrm{M}(\mathrm{S} / \mathrm{N}=3)$, and the linear response range is $1-50 \mu \mathrm{M}\left(r^{2}=0.999\right)$, which is comparable to that of $T$. versicolor laccase immobilized epoxy-RVC electrode, i,e, $0.5-80 \mu \mathrm{M} .{ }^{(1)}$ It was reported that HGA content in urine of a patient is in the range of 30-40 $\mathrm{mM}^{12.17}$ and that in plasma is in the range of $33-38 \mu \mathrm{M}^{17}$ Therefore, determination of $\mathrm{HGA}$ with the sensor reported here is possible in terms of detection limit and linear response range. Furthermore, the durable long-term stability of the sensor as long as $40-50$ days (retaining $80 \%$ of initial activity) is another advantage. The reported linear response range of the spectrophotometric enzymatic method by use of homogentisate dioxygenase is $12.5-200 \mu \mathrm{M} .^{12}$

$\mathrm{pH}$ profile of the laccase immobilized sensor for HGA shows optimal $\mathrm{pH}$ of 4.5-5.0 (Figure 5). To check the reversibility, $\mathrm{CVs}$ of $\mathrm{HGA}$ were also run on bare Pt electrode from $\mathrm{pH} 4$ to 7 (data not shown). The reversibility of HGA is worse than that of $\mathrm{HQ}$, which is responsible for the relative sensitivities for $\mathrm{HQ}$ and $\mathrm{HGA}$, because the recorded current in amperometric experiment is a reduction current, which is resulted from electrochemical reduction of the enzymatically produced oxidized form. Reversibility of HGA also does not show remarkable change upon changing $\mathrm{pH}$ in this range. Therefore, in order to explain the acidic shift of the optimal $\mathrm{pH}$ compared to that for $\mathrm{HQ}(\mathrm{pH} \mathrm{6.0)}$ the carboxylic acid side chain of HGA should be taken into account. It was reported that $\mathrm{p} K_{\mathrm{a}}$ value for phenylacetic acid is about $4.31 .{ }^{35}$ HGA will basically exist in neutural form at $\mathrm{pH}-4.3$ (or

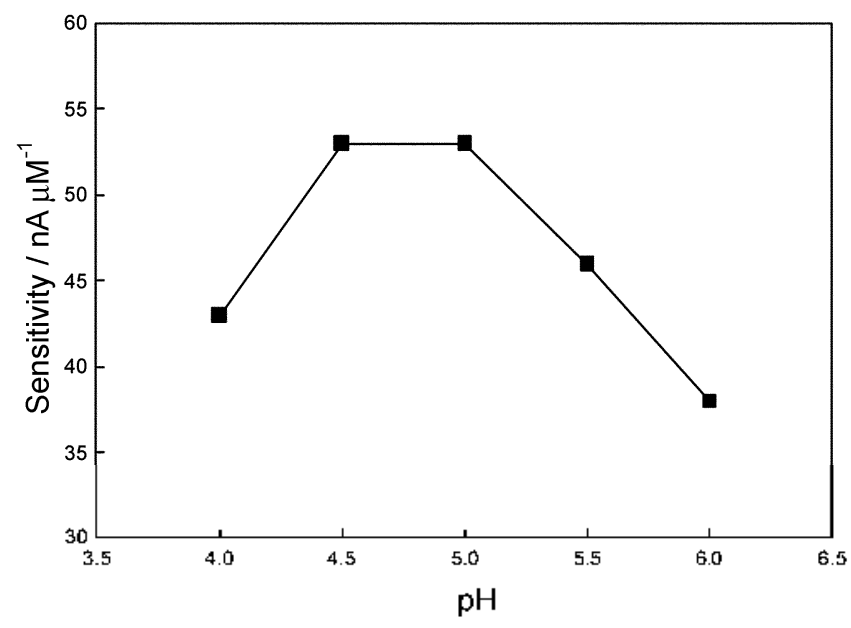

Figure 5. $\mathrm{pH}$ dependenec of the lacease immobilized Pt electrode in Mcllvaine bujler for homogentisic acid.

smaller than 4.3), which is advantageous for access of the substrate to the active site of laccase because active site of the enzyme was reported to be composed of hydrophobic patch. ${ }^{29.36}$ On the other hand, the optimal pH for Denil. ite ${ }^{\mathrm{TM}}$ laccase function is $6.0^{26}$ Therefore, optimal $\mathrm{pH}$ can be reasonably expected to be between $4.3-6.0$, and degree of the $\mathrm{pH}$ shift towards acidic range will be decided by balance of the two opposite effects as the case of catechol and catecholamines detections. ${ }^{27}$

To test the accuracy of the biosensor, several assays were made for standard substrates samples. Substrates concentrations were determined by standard curve in the linear ranges of the sensor. The current responses were normalized by the response for PPD to compensate the variations resulted from the different fabrications. Regression equations for the two substrates are as follows: $I=280.56 \mathrm{C}-453.71$ (for $\mathrm{HQ}$ ), and $I=53.36 \mathrm{C}+76.20$ (for HGA), where $I$ is current response and $\mathrm{C}$ is concentration, and units of $I$ and $\mathrm{C}$ are $\mathrm{nA}$ and $\mu \mathrm{M}$. As shown in Table 1, reliable results can be obtained. In tested concentration ranges for the two substrates, both R.S.D values increase with increase of the concentrations with R.S.D $4.2 \%$ for $\mathrm{HQ}$ and $3.5 \%$ for $\mathrm{HGA}$ at $10 \mu \mathrm{M}$. In spite of the relatively high R.S.D values the biosensor method described here do not require expensive equipment. It is possible to develop a reliable biosensor with rapidity, durability, simplicity and convenience for application

Table 1. Recovery lests of the biosensor for hydrochuinone and homogentisic acid

\begin{tabular}{lcccc}
\hline & $\begin{array}{c}\text { Added } \\
(\mu \mathrm{M})\end{array}$ & $\begin{array}{c}\text { Measured } \\
(\mu \mathrm{M})\end{array}$ & $\begin{array}{c}\text { Recovery } \\
(\%)\end{array}$ & $\begin{array}{c}\text { R.S.D } \\
(\%)\end{array}$ \\
\hline Iydropuinone & 2.5 & 2.4 & 96 & 2.8 \\
& 5.0 & 4.7 & 94 & 4.2 \\
& 10.0 & 9.4 & 94 & 4.2 \\
\hline Homogentisic acid & 2.5 & 2.6 & 104 & 2.8 \\
& 5.0 & 5.2 & 104 & 2.8 \\
& 10.0 & 10.5 & 105 & 3.5 \\
\hline
\end{tabular}

An awerage of three detections 
in real samples with good accuracy. Related work is under way.

\section{Conclusions}

The DeniLite ${ }^{\mathrm{TM}}$ laccase covalently inmobilized sensor shows fast response and durable long-term stability for hydroquinone and homogentisic acid. Detection limit for hydroquinone is in nano-molar level. The relatively higher sensitivity for hydroquinone is resulted from the better reversibility and easier access of the substrate to the active site of laccase. In spite of the relatively lower sensitivity for homogentisic acid compared to that for hydroquinone the sensor may still be used for determination of homogentisic acid in urine or in plasma of a patient in terms of detection limit and linear response range of the sensor.

Acknowledgments. The authors acknowledge the funancial support from the Korea Research Foundation (KRF-2001$042-G 00015)$.

\section{References}

1. Rueda. M. E.: Sarabia. L. A.: Herrero. A.: Ortiz. M. C. Anal. Chim. Acta 2003. 479.173

2. Vieira. I. daC. Fatibello-Filho, O: Angnes. L. Anal Chim dcta $1999,398,145$

3. Nanni, E. I.: Lovette. M. E.: Hicks. R. D.: Fowler. K. W.: Borgerding. M. F. J. Chromatogr A 1990. 505(2), 365.

4. Holstein. W. L.: Hammer. M. R.: Metha. G. F.: Buntine. M. A. Ihtem. J. Mass Spech: 2001. 207.1.

5. Zou, G.: Shi, R.: Xie, X.: Chen. H. Anal. Chim .Acta 1988. 208. 337 .

6. Sakodinskaya. I. K.: Desiderio. C.: Nardi, A; Fanali, S. J. Chromatogr. A 1992. 596( 1). 95 .

7. Levin. J.-O. Chemosphere 1988. $17(4) .671$.

8. Lee. B. L.: Ong. H. Y: Shi. C. Y.: Ong. C. N. J. Chomatogr.: Bioned Appl 1993. 619(2), 259.

9. Cui. H.: He. C.: Zhao G. J. Chromatogr. A 1999. 855,171 .

10. Wittig J.: Wittemer. S.: Veit. M. J. Chronatogr: B 2001, 761. 125.

11. He. T.: Quinn. D.: Fu. E.: Wang. Y. K. J. Chromatogr. B 1999. 727.43 .
12. Fernandez-Canon. T. M.: Penalva. M. A. Anal. Biochem. 1997. 245.218.

13. Deutsch. J. C. Santhosh-Kumar C. R. J. Chrontatogr: B 1996. 677.147.

14. Markus. A. P. J. A.; Swinkels. D. W. Jakobs. B. S.; Wevers. R. A.; Trijbels. T. M. F.: Willems. H. L. Anal Chim Acta 2001. 429. 287.

15. Valmikinathan. K: Viswanatha Rao. V. N.: Verghese. N. $J$. Chromatogr: 1966. 24. 283.

16. Akesson. B.; Forslind. K.: Woolheim. F. J. Chomatogr: Bionted. A ppl. 1987, 113, 233

17. Bory, C:- Boulieu, R: Chantin. C.: Mathieu. M. Clm. Chim. Acto 1990. $189(1) .7$

18. Barbas. C.: Garcia. A.: Miguel. L.: Simo. C. J. Chromatogr: B 2002. 780.73

19. Wasa, T; Akimoto. K: Yao. T.: Murao, S. Nippon Kagaku Kaikhi 1984. 9,1398

20. Haghighi. B.; Gorton, L.: Ruzgas, T.: Jonsson, L. J. Anal. Chin Acta 2003.487 .3

21. Wollenberger. U.: Neumant1. B. Electoomatysis 1997. $9(5) .366$

22. Mizutani. F.: Yabuki. S.: Asai. M. Biosens. Bioelectron. 1991. 6. 305 .

23. Lindgren. A.; Stoica, L; Ruzgas. T; Ciucu, A; Gorton. L. Analyst 1999. 124,527

24. Vieira. I. daC.: Fatibello-Filho. O. Talanta 2000. 52.681.

25. Quan. D.: Kiml. Y: Yoon. K.: Shin. W. Bull Korean Chem. Soc. 2002. 23. 385

26. Quan. D.: Kim. Y: Shin. W. J. Electroanal. Chent 2004, 561. 181

27. Quan. D; Shin, W. Electromallsis, Accepted.

28. Reinhammar. B. In Copper Proteins \& Copper Enzwmes; Rene. L.. Ed.: CRC Press: 1984: Vol. ПI. Chap. 1.

29. Solomon. E. I.: Sundaram. U. M.: Machonkin. T. E. Chem. Rev 1996. 96. 2563.

30. Thurston. C. F. Aicrobiologe 1994. 1+0.19.

31. Yaropolov. A. I: Skorohogatho. O. V: Vartanov, S. S. Vartolomeyev, S. D. Appl Biochem. Biotech. 1994, 19,257.

32. Kiml. Y: Cho. N.: Eoml. T.: Shinl. W. Bull. Korean Chem. Soc. 2002. 23. 985

33. Xu. F.: Shin. W.: Brown. S. H.: Wahleithner. T.: Sundaram. U. M. Solomon. E. I. Biochin. Biophys. Acta 1996. 1292, 303.

34. Wang, J Lin, Y.: Eremenko, A. V.: Ghindilis, A. L.: Kurochkin, I. N. Anal. Lell. 1993. 26, 197.

35. Harris. D. C. Onantitative Chemical Andusis. 5th Ed: W. H. Freeman and Company: New York. 1999: AP 23.

36. Ducros. V: Bizozowshi. A. M.: Wilson. K. S.: Browt1. S. H.: Ostergaard. P. Schneider, P. Yaver, D. S.: Pedersen, A. H.: Davies, G. J. Nature Struct. Biol 1998. 5(4), 310. 